NOTES 
Henri Gunanto - 9789004400603

Downloaded from Brill.comఠ4/26/2023 09:49:18AM via free access 


\section{IMPLEMENTING REGULATIONS FOR THE 1958 NEW YORK CONVENTION ON THE RECOGNITION AND ENFORCEMENT OF FOREIGN ARBITRAL AWARDS IN INDONESIA}

\section{HENRI GUNANTO*}

After the abortive coup attempt of 1965 , and the emergence of a more pragmatic 'new order' government, Indonesia opened up its gates to foreign investors. As early as 1967, a new Act on Foreign Investments was promulgated (Law No. 1, 1967'), and in 1968, Indonesia acceded to the 1965 World Bank Convention on the Settlement of Investment Disputes between States and Nationals of other States (ICSID Convention). ${ }^{2}$

As to arbitration of commercial disputes, Indonesia was not as prompt. It was not until 3 August 1981 that Indonesia acceded to the 1958 New York Convention on the Recognition and Enforcement of Foreign Arbitral Awards. ${ }^{3}$ Even after its ratification, however, the Supreme Court remained reluctant to apply the terms of the Convention. In Navigation Maritime Bulgare v. PT. Nizwar ${ }^{4}$, the Supreme Court held, in 'obiter dicta', that the Convention is not self-executing and that, consequently, implementing regulations were needed before it could be actually applied. The subject of the action was a petition of a foreign plaintiff before the Central District Court of Jakarta to obtain exequatur for an award rendered in 1978 by a London arbitration tribunal in its favor against an Indonesian company. Counsel for the foreign plaintiff pleaded applicability of the 1923 Geneva

*Gunanto, Prasasto, \& Co., Jakarta.

1. Lembaran Negara [State Gazette] 1967 No. 1.

2. Act No. 5/1968, Lembaran Negara 1968 No. 32.

3. Convention of 10 June 1958, 330 UNTS 3; Presidential Decree No. 34/1981, Lembaran Negara 1981 No. 40.

4. Decision of 29 Nov. 1984, case No. 2944 K/Pdt/1983. 
Protocol on Arbitration Clauses and the 1927 Geneva Convention on the Execution of Foreign Arbitral Awards by virtue of the applicability of the Protocol and the Convention in the former Netherlands East Indies ${ }^{5}$ in conjunction with transitory constitutional provisions. ${ }^{6}$ On 10 June 1981 , i.e., before the Indonesian accession to the 1958 New York Convention, the District Court granted the exequatur. In accordance with the relevant provisions $^{7}$ of the Code of Civil Procedure ${ }^{8}$, the original defendant appealed for cassation to the Supreme Court. ${ }^{9}$

The panel of three Justices of the Supreme Court ${ }^{10}$ under the chairmanship of Justice ASIKIN ${ }^{7}$ dismissed the petition for cassation on the formal ground that the defendant-petitioner had not submitted the necessary pleadings, whereupon the Supreme Court did not consider the merits of the case. Instead, it considered necessary to state its opinion regarding the enforceability of foreign judgments and arbitral awards in Indonesia "for the sake of legal security and the development of law in Indonesia".

The Court held that:

(i) in accordance with previous decisions of Indonesian courts in similar actions ("Yurisprudensi"), in principle no foreign judgment or arbitral award is enforceable in Indonesia unless a treaty to that effect has been concluded between Indonesia and the other country concerned;

5. Stb.N.I. 1933 Nos. 131 and 132.

6. Transitory Provisions, Art. II, of the 1945 Constitution: "All existing State institutions and laws shall remain in force until replaced in accordance with this Constitution."

7. Article 641 .

8. The Code of Civil Procedure (Dutch: Rechtsvordering, 'RV') was applicable to actions before the pre-Independence courts for European litigants, called 'Raad van Justitie'. For the segregated courts for Indonesians at that time a set of simplified 'Rules of Procedure' applied. After independence Indonesia established a system of unified courts which apply these simplified Rules of Procedure. However, in respect of causes of actions not provided for in these Rules, the courts still apply the relevant provisions of the 'European' Code of Civil Procedure. This is also the case where the Rules of Procedure specifically refer to pertinent provisions of the Code. Among these 'borrowed' provisions of the Code of Civil Procedure are those of its Title 3, Chapter 1, concerning arbitration procedures and the execution of arbitral awards, including specific provisions for appellate review (Article 641 et seq.). Art. 377 of the Rules of Procedure reads: "Insofar as Indonesians and other Asians intend to submit their disputes to the decision of arbitrators, they shall act in accordance with the relevant provisions for Europeans".

9. Article 641 of the Code of Civil Procedure actually provided for 'de novo' appeal from the courts of first instance to the highest court of the colony. In the republican court system the Supreme Court is a court of cassation.

10. All Indonesian courts sit with 3 judges or justices.

11. Within the internal organization of the Supreme Court, Justice Asikin is the Vice-President of the Supreme Court for Codified Law Affairs. 
(ii) notwithstanding Article 5 of the Agreement on Transitional Measures [as part] of the Round Table Conference Agreements ${ }^{12}$, providing for the continued applicability to the Indonesian Republic of treaties which applied to the Indonesian territory, yet the Republic of Indonesia is not absolutely bound by the aforementioned Round Table Conference Agreement, nor by international agreements which have been concluded in the past by the government of the Kingdom of the Netherlands. This is so since these international agreements (specifically those referred to in the State Gazette of 1933 No. 32 [i.e., the Geneva Convention on the Recognition and Enforcement of Foreign Arbitral Awards of 26 Sep. 1927]) were concluded at a time when the world was completely controlled by Colonial Powers, and since, as a consequence, the international law principle of state succession too was affected by the prevailing situation, to the effect that colonies, upon attaining independence, would (in accordance with the so-called Passive System) be automatically bound by the international agreements concluded by its Colonial Power;

(iii) that since the Second World War the constellation of the world has changed because of the emergence of new forces such as the developing countries, and by the current conception of interdependence which essentially refers to the common concern of the family of nations for the state of the world;

(iv) in accordance with obtaining legal practice, [the enforcement of the 1958 New York Convention on the Recognition and Enforcement of Foreign Arbitral Awards which has been ratified] must still await implementing regulations on such matters as whether exequatur may be applied for directly from the District Court, and if so, at which venue, or whether the application should be addressed to the Supreme Court in order to have the arbitral award tested on whether or not it is in conflict with Indonesian 'public policy'.

Indonesians may have no difficulty in accepting that the RTC Agreements are obsolete and that Indonesia does not necessarily succeed the Netherlands Indies in treaties acceded to by the Netherlands for its colony in the past. In respect of the 1958 New York Convention, which is ratified by Indonesia itself, however, the question arose whether any special implementing regulation was at all necessary. According to one opinion, the Code of Civil Procedure, which the Indonesian district courts apply in actions regarding the enforcement of arbitration award pursuant to its own Rules of Procedures (supra), lends itself with no difficulty for application to foreign arbitral awards. As a matter of fact, Article 634 of the Code of Civil Procedure provides that any one of the arbitrators or an attorney with proper power shall within certain time limits present the original or authenticated copy of 'the award' to the Registrar's Office of the court of first

12. By which the Netherlands and Indonesia arranged the formal transfer of sovereignty over the Indonesian archipelago. 
instance in whose district the award was rendered for the filing of the judgment. Article 639 further provides that the award shall then be enforced by order of the President of the court in an 'ordinary manner'. This could be construed to mean that the execution shall be carried out in the manner provided by the Rules of Procedure. Admittedly, this argument is an indirect approach: neither the Code of Civil Procedure nor the Rules of Procedure contain specific provisions on the enforcement of foreign arbitral awards. ${ }^{13}$

Underlying the criticism against the 'obiter dicta' considerations of the Supreme Court was the concern of business circles that they may harm the national interests in international economic relations. Under consistent community pressure, the Supreme Court made a surprise decision on 1 March 1990, by issuing its own rules to fill the gap which it had found to exist.

The Supreme Court Rules No. 1/1990 concerning Procedures for the Enforcement of Foreign Arbitral Awards are basically meant as supplementary rules of procedure to be observed by the lower courts, and provide for the Central District Court of Jakarta to have exclusive jurisdiction over matters affecting the recognition and enforcement of foreign arbitral awards. ${ }^{14}$ Recognition and enforcement shall only be granted on basis of reciprocity with the forum country of the award 15 and shall be restricted to awards in respect of causes of action which according to Indonesian law would fall within the scope of commercial law 16 and which are not contrary to 'public policy'. ${ }^{17}$ Enforcement shall furthermore be subject to prior exequatur from the Supreme Court ${ }^{18}$. Power to grant such exequatur is vested in the President of the Supreme Court but may be delegated to the Deputy President or the Vice-President of the Court for Codified Law Affairs. ${ }^{19,20}$

13. Note the second preamble of the new Rules No. 1/1990, infra, considering that these implementing regulations for the 1958 New York Convention are necessary because the existing Rules of Procedure as well as the Code of Civil Procedure do not provide for the enforcement of foreign arbitral awards, although in its substantive provisions the Rules refer the lower court to the relevant articles of the Rules of Procedure, which articles in turn refer to the Code of Civil Procedure.

14. See Art. 1.

15. See Art. 3 para. (1).

16. See Art. 3 para. (2).

17. Art. 3 para. (3); Art. 4 para. (2).

18. Art. 3 para. (4).

19. Art. 4 para. (1).

20. Indonesia is a bilegal system where codified or written law exists side by side with unwritten or customary law ('adat' law). 
The exequatur procedure calls for the filing of the arbitral award with the Office of the Registrar of the Central Jakarta District Court in accordance with (Article 377 of) the Rules of Procedure which essentially provides that arbitration is subject to the provisions of the Code of Civil Procedure. ${ }^{21}$ Under these provisions the foreign award, together with the letters of appointment of the arbitrators, would have to be filed with the Central District Court of Jakarta within 3 months from the rendering of the award. Awards which were rendered after the entry into force for Indonesia of the 1958 New York Convention but before the promulgation of the Rules would generally be more than three months old towards the effective date of the Rules so that a strict construction of the time bar would exclude these awards from exequatur. The relevant provision of the Code of Civil Procedure may therefore have to be interpreted so as not to lead to such unsatisfactory results.

Article 5 of the Supreme Court Rules No. 1/1990 provides that the President of the Central District Court of Jakarta must transmit the file of the case to the Secretary General of the Supreme Court within 14 days after receipt of the application in order to obtain the necessary exequatur. The file must include a statement of the Indonesian diplomatic representative in the country where the award has been rendered to the effect that the state of the petitioner and Indonesia are both parties to a convention on the recognition and enforcement of foreign arbitral awards or that the two States are bound by a similar bilateral treaty. This latter part of the provision is inconsistent with Article 3 para.(1) of the Rules which requires reciprocity with the forum country of the award, not the state of the petitioner. These may be two different countries.

The foreign award shall not be recognized and the Supreme Court shall not grant exequatur for the execution if it would be contrary to "public policy'. Article 4 para. (2) of the Supreme Court Rules defines such 'public policy' as 'fundamental principles of the entire legal system and society in Indonesia'.22

21. See supra, the discussion on Art. 634 of the Code.

22. Although not mathematically tight, this definition distinguishes 'public policy' in international relationships from 'public order' in domestic transactions. The latter is referred to in article 23 of the 'General Principles of Legislation' ('Algemene Bepalingen van Wetgeving', Stb.N.I. 1847 No. 23, still applicable by virtue of Art. II of the Transitory Provisions of the 1945 Constitution.) which may be construed as referring to all mandatory laws such as criminal law, administrative law and contract law provisions affecting 'public order and morals'. 